\title{
The Effects of Information and Social Cleavages: Explaining Issue Attitudes and Vote Choice in Canada
}

\author{
Amanda Bittner, Doctoral Candidate \\ Department of Political Science, University of British Columbia \\ bittnera@,interchange.ubc.ca \\ C425 - 1866 Main Mall \\ Vancouver, B.C. V6T 1Z1
}

\begin{abstract}
This paper examines the relationship between social group identity and level of political information in explaining Canadians' issue attitudes and vote choices. Traditional accounts of Canadians' partisan political leanings have placed a great deal of emphasis on social group identity in explaining attitudes. However based on data from the Canadian Election Studies from 1988-2004, it is argued that both social group identity and information influence the nature of vote choice and public opinion in Canada. In fact, level of voter information has two contradictory effects on the political attitudes of different social groups. In some cases voters' level of information reduces the role of social group identity in explaining attitudes and vote choices; information acts to 'bridge' the differences between different social groups (for example Catholics/non-Catholics and urban/rural Canadians). In other cases, voters' level of information acts to 'amplify' the importance of social group identity in predicting attitudes (for example women/men and religious/non-religious). These findings suggest that not only is social group identity a less effective predictor of attitudes than has traditionally been thought; but that there are also significant underlying differences between the so-called 'old' and 'new' cleavages in Canada when it comes to understanding their impact on political values.
\end{abstract}

Résumé: Ce texte examine la relation entre les bases sociologiques et le niveau d'information politique dans l'explication des attitudes vis-à-vis des questions d'intérêt politique et des choix de vote des Canadiens. Les analyses traditionnelles des appuis aux partis des Canadiens ont affirmé que les bases sociologiques sont d'une grande importance pour expliquer les attitudes. Cependant, en nous appuyant sur les données des Études électorales canadiennes de 1988 à 2004, nous défendons la thèse selon laquelle à la fois les bases sociologiques et l'information influencent la nature du choix de vote et de l'opinion publique au Canada. En réalité, le niveau d'information des électeurs produit deux effets contradictoires vis-à-vis des attitudes politiques des différents groupes sociaux. Dans certains cas, le niveau d'information des électeurs réduit le rôle de la base sociologique dans l'explication des attitudes et des choix de vote ; l'information est un moyen d'outrepasser les différences entre divers groups sociaux (par exemple catholiques/non-catholiques et Canadiens en milieu urbain/rural). En d'autres cas, le niveau d'information des électeurs "amplifie" l'importance de la base sociologique en prédisant les attitudes (par exemple femmes/hommes et religieux/non-religieux). Ces découvertes suggèrent que la base sociologique est un indicateur moins efficace que les analyses traditionnelles ne le supposent pour prédire les attitudes. De surcroît, il y a des différences sousjacentes et importantes entre les soi-disant "anciens" et "nouveaux" clivages au Canada pour comprendre leur impact vis-à-vis des valeurs politiques. 
Acknowledgements: $\quad$ This paper was made possible as a result of the support of the Social Sciences and Humanities Research Council of Canada, in the form of a doctoral fellowship. Earlier versions of this paper were presented at the Canadian Political Science Association's Annual Meeting in Toronto and at the Atlantic Provinces Political Science Association's Annual Meeting in Halifax. I would like to thank this Journal's two anonymous reviewers for their feedback, and I am especially grateful to Richard Johnston, Fred Cutler, Scott Matthews, and Ben Nyblade, for comments and suggestions received in the preparation of this paper, to Jean-Francois Godbout, Francois Pétry, and Joanna Everitt for their helpful comments at the CPSA and APPSA, and to Jean-Philippe Ranger for help with translation of the abstract. Of course, none of these individuals are responsible for any arguments or errors in this paper. 


\section{Introduction}

For years, Canadian political scientists have identified a number of social cleavages which have been thought to have a substantial impact on citizens' attitudes, opinions, and vote choice. While the origins of these social cleavages have been debated extensively (usually in this Journal), ${ }^{1}$ it is generally accepted that social identities shape political values. Some studies have suggested that 'Catholics vote Liberal' (Bélanger and Eagles 2005; Blais 2005; Irvine and Gold 1980; Johnston 1985). Others have observed that individuals of non-European origin also vote Liberal (Blais 2005; Blais et al. 2002). Others still have argued that rural Canadians tend to be more socially conservative than those living in urban areas (Cutler and Jenkins 2002); that women are more 'left-wing' than men (Gidengil et al. 2003); and that 'the west' tends to vote differently than 'the east' (Blais et al. 2002). These observations about the impact of social group identity on political attitudes fit within a wider literature on voting behaviour which has identified the importance of the social group since the earliest election studies (Berelson et al.1954; Lazarsfeld et al. 1944).

More recently, some scholars have argued that social group identity may do more than simply help to explain vote choice. A subset of research within the voting behaviour literature has examined citizens' reasoning processes, and in particular, how it is that individuals are able to make decisions with little or no information. Some studies have suggested that group identification may act as a shortcut, helping individuals to overcome a lack of knowledge and information when arriving at political preferences (Brady and Sniderman 1985; Sniderman et al. 1991). In contrast, however, others have shown that with increased exposure to the media, individuals rely less upon group identity when forming preferences (Mendelsohn and Nadeau 1997).

Mendelsohn and Nadeau's (1997) results hint at a relationship between voters' social group identities and information levels that conflict with the notion of the social group as a simple shortcut, and leave us with an important and unresolved question: what is the relationship between social group identity and levels of information in explaining attitudes and vote choice? And, further, how do these two factors interact to influence the decisions made by citizens? The studies cited above allow us to hypothesize three potential outcomes of the interaction between 
social group identity and information. The first possibility is that information serves to 'bridge' group differences, meaning that the differences between social groups are minimized with higher levels of information (as Mendelsohn and Nadeau found with regards to the effects of media exposure on the differences between Catholics and Protestants). The second possibility is that information may have no effect on the impact of social group identification; and the third possibility is that information may serve to reinforce differences between social groups along cleavage lines - for example, with higher levels of information, Catholic voters would become more likely to vote for the Liberal Party.

Using data from the Canadian Election Studies, ${ }^{2}$ this paper investigates these possibilities empirically, and finds that information has contradictory effects for different types of cleavages. In some cases, voters' level of information reduces the role of social group identity in explaining attitudes and vote choices: information acts to 'bridge' the differences between different social groups. In other cases, increased levels of information act to 'amplify' the importance of the social group identity in predicting attitudes. Furthermore, these findings suggest that there are important underlying differences between so-called 'old' and 'new' cleavages in Canada when it comes to understanding their impact on political values.

\section{Social Cleavages}

The notion that social group identification affects voting behaviour and attitudes dominates Canadian literature but is not a Canadian artifact. The earliest election studies first gave evidence of the influential role of social group membership. Berelson et al. (1954) found that political choices were being transmitted socially, and they pointed to the importance of context, arguing that individuals were influenced by family members, the community, and the work environment. Social factors are also understood to explain the formation of party systems. In their seminal work, Lipset and Rokkan (1967) pointed to the existence of long-standing cleavages that helped to structure vote choice and partisanship. They argued that contemporary party systems reflect traditional cleavage structures in society, whether religious, territorial, cultural, or economic.

Simply put, it has been widely thought that social group membership affects political actions and political behaviour, by structuring the way that individuals see and interpret the 
political world. Indeed, the search for a better understanding of the determinants of attitude, opinion, and vote choice in Canada has historically tended to emphasize the study of social group membership (Siegfried 1907; Irvine and Gold 1980; Johnston 1985; Gidengil et al. 2003). More recently, the importance of social group identification was highlighted by André Blais' (2005) Presidential address to the Canadian Political Science Association, and he rekindled a longstanding interest in unpacking the relationship between social group identification and vote choice, as he argued that we really do not know much about why the social group has had such a large impact on attitudes. This paper fills in some of the blanks, focusing primarily on the religious cleavage, the regional cleavage (specifically urban versus rural) and the gender gap, because of their prevalence in the literature, and the efforts scholars have made to understand the effects of these cleavages on voting.

\section{The Religious Cleavage}

"Catholics vote Liberal," Blais told us, summarizing a century of scholarship—kickstarted by Andre Siegfried in the early 1900s - that pointed to the dividing role of religious affiliation in Canada. John Meisel's (1956) findings reiterated the existence of this religious division in Canada, when he pointed to the "highly one-sided voting record of the Roman Catholics." Findings by Irvine (1974) and Irvine and Gold (1980) also supported this claim, as they argued that Liberal-leaning tendencies among Catholics were the result of family socialization. Later, Johnston (1985) took their work one step further, suggesting that family socialization was not enough on its own. Johnston brought the debate back to the roots of voting behaviour literature and drew from Berelson et al.'s (1954) observations regarding the social bases of voting behaviour. He argued that in addition to family socialization, the influence of the community as a whole was crucial to understanding the stability and reproduction of the religious cleavage.

Despite all this work, we still remain in the dark as to why it is that Catholics vote Liberal. Blais explored a number of possible explanations, from the Party's policies, to its leadership, to issue attitudes held by Catholics, but suggested that in the end, none of these

factors really explain the link between Catholics and the Liberal Party. We still don't know why Catholics vote Liberal, but some recent scholarship suggests that perhaps the link has nothing to do with the Party's policies and whether or not they benefit Catholics in any real sense. 
Mendelsohn and Nadeau (1997) found that Catholics and Protestants were not very different when they had similar levels of exposure to the media, and they argued that priming can affect the nature of party evaluation, as the media ignore religious cleavages while emphasizing divisions on the basis of region and language. Their analysis supports the notion that the religious cleavage is fundamentally about a social group identification or 'group think,' not necessarily grounded in any particular group interest.

\section{Regional Cleavages: Urban versus Rural}

The status of the urban/rural cleavage is similar to that of the religious cleavage, in that it is regarded as one of the main cleavages in Canadian politics. Among other regional cleavages, it exercises a strong influence on voting behaviour. For example, Blais et al. observed different levels of support for the Canadian Alliance in the 2000 Canadian federal election, noting that "rural areas tended to be the party's strongest supporters" (2002: 93), while the Liberals had more success among urban voters than rural voters. Their findings support those of Cutler and Jenkins (2000), who found rural voters to be more socially conservative than urban voters. Why this difference exists is not known for certain, but it tends to be explained to students of Canadian politics in terms of resource bases and regional alienation-introductory textbooks outline in great detail the heartland/hinterland cleavage and the historical foundations of those differences. $^{3}$

While the distribution of resources may be a factor, the perpetuation of those value-based differences is likely to be a result of the inheritance of community values from generation to generation in much the same way as first introduced by Berelson et al. (1954). Interestingly, Cutler and Jenkins point to the mediating role of education which they suggest may reduce the differences between urban and rural dwellers, a reduction consistent with that observed by Mendelsohn and Nadeau (1997), that media exposure reduces 'group think.' At the very least, these studies suggest that information may play a role in affecting the importance of social cleavages in determining vote choice - in particular, that information may serve to 'bridge the gap' between social groups, making them less different in their attitudes and voting behaviour.

\section{The Gender Gap}


Research in political behaviour has for some time now pointed to the existence of a 'gender gap,' between the political attitudes of men and women. Heather MacIvor has observed that "numerous American and Canadian studies have found that men and women tend to hold different attitudes on some political issues: war and peace, nuclear power, capital punishment, and social welfare spending" (1996: 233). In the past, women were thought to be "...more frequently apathetic, parochial, conservative, and sensitive to personality, emotional, and esthetic aspects of political life and electoral campaigns" (Almond and Verba 1963: 325). More recent research demonstrates that the gender gap still remains, though male/female attitudes have shifted. Ronald Inglehart and Pippa Norris argued that “...women are no longer more conservative than men, and are often more left-leaning, in many established democracies" (Inglehart and Norris 2000: 446).

Some suggest that a transformation of sex-roles has affected this shift in the gender gap (Inglehart and Norris 2000), while others point to changes in socio-demographic characteristics of the population. Joanna Everitt (2002) has suggested that employment levels and reliance on the welfare state, the development of a gender-consciousness, and changing patterns of socialization have led to the development of the gender gap in political attitudes. A similar argument has been put forth more recently by Torben Iversen and Frances Rosenbluth (2006).

Gidengil et al. (2003) also explored a variety of explanations for the gender gap, including structural factors and socio-psychological explanations, and their findings suggested that socio-psychological origins prove to be a more robust explanation of differences of opinion. They argue that the gender gap "could not be explained in terms of differences in women's and men's material interests" (2003:154). However, they also noted that women's autonomy, education, and marital status also affect opinion, all of which suggests that there is more to the gender gap than simply a psychological state of mind. That education affects the nature of the gender gap again suggests that information and knowledge may play an integral role in influencing the effect of social group identity on vote choice. Simply put, knowledge and information are important.

\section{The Uninformed Citizen - The Role of Information in Voting Behaviour}


In one of the earliest studies of voting behaviour, Campbell et al. (1960) observed the lack of interest and knowledge among the majority of voters, and found that both were closely associated with education - that is, that people with more education tended to be more interested in and knowledgeable about politics (1960:25). These findings were reinforced by Converse's (1964) seminal work, in which he found that the mass public had little understanding of basic political concepts (for example, left/right dimensions), and that the political ideas that voters did possess lacked constraint or consistency both horizontally (across ideas) and longitudinally (over time). The implications of these findings were devastating for notions of democracy which expected individuals to have some basic understanding of politics in order to be able to articulate their own interests. What is the point of democracy if citizens lack coherent attitudes and beliefs?

In the last 40 years, political scientists have made significant efforts to address this "democratic dilemma" "and have responded to the problems raised by Converse's article in four main, and often related, ways. The first is the group (spearheaded by the efforts of Christopher Achen) that suggests that Converse's findings are largely a result of measurement error. Using the same data as Converse, Achen (1975) suggested that the issue was really the reliability of the measures themselves - what was the likelihood that an individual with unchanged values would give the same answer time after time? He argued that the problem was not that respondents are 'thick-headed,' but that survey measures themselves are problematic. In contrast, a second group within the literature suggests that in fact, the lack of attitude stability seems to sort itself out at the aggregate level - that any inconsistencies that may exist at the individual level are not present at the aggregate level, thus the electoral outcomes are unaffected (Converse and Pierce 1986; Kramer 1971; Page and Shapiro 1992; Wittman 1989).

A third strand seeks to understand what constitutes citizen knowledge, and to specify what it is that citizens actually need to know (Delli Carpini and Keeter 1996; Lupia and McCubbins 1998). The results among this group are mixed, as some scholars argue that citizens tend not to have the information they need (Delli Carpini and Keeter 1996), while others suggest that they have the capacity to make reasoned choice using the tools available to them (Lupia and McCubbins 1998).

A fourth strand, closely related to the third, consists of a group of scholars seeking to understand how it is that citizens reason about politics, combining political science with social and cognitive psychology (Brady and Sniderman 1985; Conover and Feldman 1989; Fiske 1986; 
Hamill, Lodge, and Blake 1985; Sniderman, Brody, and Tetlock 1991). Some in this fourth tradition have attempted to ascertain whether citizens are able to overcome their information shortfalls by using a series of cognitive tools (Brady and Sniderman 1985; Sniderman, Brody, and Tetlock 1991). These scholars have suggested that perhaps individuals use heuristics or information "short-cuts" to come to the same decisions they would make if they were fully informed. Further, they have pointed to a key role for social group identity and affinity with different social groups, suggesting that group affiliation can in fact act as a short-cut for uninformed voters. The idea here is that the less informed are able to make the same kinds of decisions as those who are more informed by relying on identification with the social group. This points to an important link that might exist between the roles of 'social group' and 'information,' but the nature of the relationship is unclear: does information/knowledge affect the role of the social group identification, or does social group identification help to overcome a lack of information? If the social group acts as a shortcut for decision-making, then information should not really have a role - within a given social group, those who are less informed should behave similarly to those who are more informed. If, however, information affects the impact of social group identity, then we can realistically expect one of two outcomes - outcomes which I have labeled 'bridging' and 'amplifying' effects. Information may either reduce the impact of the social group, thus 'bridging the gap' between groups as identified by both Mendelsohn and Nadeau (1997) and Cutler and Jenkins (2000), or it may amplify the effect, causing the different social groups to behave even more dramatically in opposing directions (for example, among the more informed, Catholics would vote in even larger numbers for the Liberal Party compared to non-Catholics).

\section{Modeling the Role of Information, 2004}

In order to study the effect of information on social group attitudes in Canada, this study built upon a research method introduced by Larry Bartels (1996), applying his methodology to data from the 2004 Canadian Election Study. The 2004 survey data provide indicators for a substantial number of the questions and variables being examined, including vote choice and issue attitudes, as well as an extensive battery of factual questions that can be used to establish the level of information or political knowledge held by respondents. In this paper, the theory behind the concept of 'information' is borrowed from others. In the introduction to their (1995) 
book Political Judgment, Kathleen McGraw and Milton Lodge pointed out that information is distinct or separate from data - they suggested that information is the knowledge possessed by a given person, while data are the inputs available in the environment (McGraw \& Lodge 1995:2). The information measure used in this analysis incorporates the knowledge possessed by respondents in the CES, based on their responses to a series of factual questions. For now, we leave out the issue of where this information was obtained.

In the first half of his (1996) paper, Bartels sought to test the notion that those with lower levels of information were able to make decisions as if they were fully informed. He ran a series of probit analyses with vote choice as the dependent variable and a battery of demographics as the independent variables. In order to determine the effects of information, he included a "complete set of interactions between political information and all of the other explanatory variables in the analysis" (1996:205). While Bartels employed the interviewer rating of political sophistication as his information measure, for the present study an index was constructed, based on 14 factual questions that respondents were asked in the 2004 survey. This measure was chosen over another for two main reasons: first, these data were available; and second, because this type of data appears to provide the most robust indicator of political information or knowledge (Zaller 1986). Figure 1 illustrates the distribution of correct responses to the factual questions posed in the CES, excluding Quebec respondents. Not surprisingly, the distribution tends to be slightly skewed: most respondents did not answer all of the questions correctly.

$<$ figure 1 about here $>$

In creating the information index, respondents were coded at " 0 " if they had no correct responses at all and at " 1 " if they had correctly responded to all 14 questions. Their political choices were then analyzed in conjunction with their level of political information.

In addition to the information indicator, Bartels' method was diverged from in one other significant way: vote choice was not the only dependent variable in this study. Attitudes towards four traditionally 'contentious' issues in Canadian politics were also examined, to determine the effects of information on attitudes and opinion. These four issues include: whether or not Canada should have closer ties to the United States; whether or not Canada should do more for Quebec; attitudes towards abortion; and attitudes towards same sex marriage. This study separates voters in the rest of Canada from those in Quebec, normal practice in the study of Canadian elections 
and public opinion (see, Johnston et al. 1992; Mendelsohn and Nadeau 1997), due to the substantially different nature of the political contest within Quebec. ${ }^{5}$

The issues chosen represent 'old' and 'new' issues in the Canadian political landscape, and vote choice for the Liberal and Conservative parties was chosen over other parties because of their dominance in Federal electoral politics.

A typical model for either vote choice or issue preference is as follows:

$$
\operatorname{prob}\left(\mathrm{Y}_{i}=1\right)=\Phi\left(\Sigma_{k}\left[\alpha_{k}\left(1-\mathrm{W}_{i}\right) \mathrm{X}_{i k}+\omega_{k} \mathrm{~W}_{i} \mathrm{X}_{i k}\right]\right)
$$

where $\Phi$ is the cumulative normal probit function, $Y_{i}$ is the respondent's reported either a) vote choice or b) issue attitude (both of which are dichotomous variables as coded in the analysis), and $\mathrm{W}_{i}$ is respondent $i$ 's level of political knowledge/information on the $0-1$ scale. $\mathrm{X}_{i k}$ is the respondent ( $i$ 's) score on a given characteristic $k$ (woman, education, etc.), $\omega_{k}$ and $\alpha_{k}$ are both estimable parameters which reflect the effect of $k$ on vote choice or issue attitude of both uninformed and informed respondents. The functional form is identical to that presented by Bartels (1996), and more information about the model can be found in his paper.

The model thus includes both the demographic variables as independent variables (generally coded as 0/1 dummy variables), as well as these same demographics interacted with the information indicator. In order to compute the coefficients for fully informed preferences, the value of the linear combination of parameters was obtained. In keeping with Bartels' methodology, the coefficients and standard errors for the uninformed preferences (for example, age) were combined with the coefficients and standard errors of the interacted information effect (age*knowledge). ${ }^{6}$ This model thus uncovers the effects of the social group basis of choice as well as the information effect. Other factors are also likely to play a part in determining overall issue attitudes and vote choice - for example, party identification, perceptions of the economy, and attitudes towards party leaders, among other things. In order to reduce the effects of multicollinearity, these other variables were left out of the model: it was assumed (as others have before: see for example, Campbell et al. 1960, Miller \& Shanks 1996) that socioeconomic characteristics have an impact both on the other potential explanatory variables as well as the dependent variables in the analysis and therefore these additional variables were excluded. ${ }^{7}$ 
Furthermore, these additional explanatory variables are also likely to be affected by information itself. ${ }^{8}$ It is to unpacking the effects of information and social group identity that I now turn.

\section{The Effect of Information on Opinions and Attitudes, 2004}

The findings of this study confirm those of Bartels (1996). Simply put, the less informed do not behave as the more informed. Table 1 illustrates the role of information in affecting the impact of the demographic variables. In some cases, information actually has the effect of reversing the nature of the impact of the demographic variable, resulting in a 'bridging' effect between Catholics and non-Catholics. For example, among uninformed voters, Catholics are substantially less likely to vote for the Conservative party than are non-Catholics, fitting with our current understanding that Catholics vote Liberal. However, the information effect for Catholics is actually positive (and statistically significant), with higher levels of information indicating an increased probability that a Catholic will vote Conservative. The effect of information on urban voters is similar: while not approaching traditional levels of statistical significance, the data provide us with a general indication that uninformed urbanites are less likely to vote Conservative than uninformed rural Canadians, but that increased levels of information reduce this tendency.

$<$ table 1 about here $>$

The effect of information on the influence of social group identity is apparent not only in relation to vote choice, but in relation to issue attitudes as well. Table 2 (below) illustrates the effect of information on attitudes related to same sex marriage. ${ }^{9}$

$<$ table 2 about here $>$

Similarly to its effect on Conservative vote choice, information results in differing levels of support for same sex marriage within each social group. Informed women are slightly more likely to support same sex marriage than are uninformed women. Informed Atheists are slightly more likely to support same sex marriage than are uninformed Atheists. In contrast, the effect of 
information on the probability of support for same sex marriage among married individuals is the opposite, resulting in a lower likelihood of support for same sex marriage. Clearly, information plays a role in public opinion-but how much of a role?

\section{Understanding the Role of Information}

What, then, exactly is the effect of information on voting and opinion? Since the Tables above report probit estimates, the coefficients are not terribly straightforward to interpret, therefore the effects of information for different demographic characteristics were also estimated using 'Clarify' software (see Tomz, Wittenberg \& King 2003 for details). The figures below illustrate the impact of information on the influence of the social group on opinion regarding the four specific issue areas. Clarify generates quantities of interest for all the estimated coefficients in the model (regardless of initial standard error) as well as standard errors and confidence intervals for predicted values and first differences, such as those presented in this analysis. While one might be concerned about these data, given that not all coefficients presented in Tables 1 and 2 reach traditional levels of statistical significance, Clarify generates standard errors and confidence intervals for the computed values, many of which do reach traditional levels of statistical significance. There is no question that some of the information effects presented below may be the result of random variation. Subsequent discussion of the values presented will make note of the statistical significance, to make it clear for readers what is significant (and more importantly, what is not), but it is also the case that the substantive significance of the data also

merits discussion. ${ }^{10}$ One can be confident that the information effects presented below are broadly indicative of the 'real' effects of information for the social groups involved in the analysis. It is also reassuring that effects of equivalent magnitude and direction persist over time.

\section{Catholics}

Figure 2 illustrates the effect of information on opinion among Catholics. Uninformed Catholics are approximately eight percent more likely than non-Catholics to support closer ties to the United States, while informed Catholics are nearly ten percent less likely than non-Catholics to support closer ties: information results in nearly a 20 percentage point drop in support for 
closer ties to the US. In contrast, uninformed Catholics are not in favour of doing more for Quebec, and information results in a slight increase in the probability of support for this issue.

$<$ figure 2 about here $>$

A similar effect is evident when it comes to support for same sex marriage. Uninformed Catholics are ten percentage points less likely than uninformed non-Catholics to support same sex marriage. With increased information, we see a ten percentage point increase: the probability of supporting same sex marriage increases and becomes positive, leaving informed Catholics not really any different from informed non-Catholics.

It is only on the issue of abortion that information serves to reinforce the divide between Catholics and non-Catholics - informed Catholics are slightly less supportive of easier access to abortion than are uninformed Catholics, however we should not read too much into the abortion line, as the magnitude of change is small, and the means did not achieve traditional levels of statistical significance. The importance of this graph is that taken as a whole, these data suggest that we cannot necessarily generalize about a Catholic "ethos" for the entire group: informed Catholics hold different opinions than uninformed Catholics.

\section{Women}

Figure 3 illustrates the effect of information for women. As can be seen from the graph, the 'gender gap' identified in Canadian politics (Gidengil et al. 2003) appears to widen on a number of issues when individuals are more informed. Women become more left-leaning when it comes to both abortion and attitudes toward same sex marriage, and the changes in both achieve traditional levels of statistical significance.

On the issue of same sex marriage, uninformed women were approximately $20 \%$ more likely to support same sex marriage than were men, and information had the effect of widening that gap, bringing the probability of support up to nearly $29 \%$ higher than men. Information had a similar (and larger) effect on the support for easier access to abortion. Uninformed women were approximately five percent less likely than men to support easier access to abortion, and information has the effect of increasing the probability of support for easier access to abortion to nearly ten percent: an increase of nearly 15 percentage points. 
$<$ figure 3 about here $>$

The effect of information is equally substantial with regards to the issue of ties to the United States. As the bottom-most line indicates, uninformed women are only slightly (2\%) less likely to support closer ties to the US than are uninformed men, while fully informed women are $17 \%$ less likely to support closer ties to the US than are informed men. Similarly to the effect of information on attitudes towards abortion, information results in a change in probability of support for close ties to the US by approximately $15 \%$. Again, these data indicate that information has the effect of widening the gender gap: the value differences between women and men are most pronounced among the most informed.

In addition to confirming the findings of others, these results indicate that information does not only have a substantial effect for 'new' issues (for example, same sex marriage) where there might be more uncertainty and less information overall, but also has an important effect for issues that have played a role in Canadian politics for decades. Simply put, information appears to affect the nature of opinion and decision-making, regardless of how long 'information' on a given issue has been around.

\section{Atheists/Non-Religious}

While research on the role of religion in shaping Canadian attitudes has traditionally focused on the difference between Catholics and Protestants (Bélanger and Eagles 2005; Irvine and Gold; Johnston 1985; Mendelsohn and Nadeau 1997), the large number of individuals who claim to be atheists or to have no religion ${ }^{11}$ is growing, and is substantial enough to warrant a look at their values. A quick scan of the 2004 CES data indicates that while Catholics remain largest in number, the number of non-religious respondents is relatively similar to (although smaller than) the number of Protestants. ${ }^{12}$ Table 3 illustrates the breakdown of these three groups within the total sample, and also specifically among voters.

$<$ table 3 about here $>$ 
The effect of information on opinion and vote choice among the non-religious is similar to the effect on women. That is, with more information, the non-religious become more supportive of same sex marriage and abortion. Figure 4 illustrates the effect of information on vote choice and issue attitudes within this group.

$<$ figure 4 about here $>$

With increased information, the non-religious become increasingly supportive of both same sex marriage and easier access to abortion, and at the $95 \%$ confidence level, the differences are significant across the range of information. Fully informed individuals are approximately 10 percentage points more supportive of same sex marriage than are uninformed individuals (jumping from $18 \%$ to $28 \%$ ), while fully informed individuals are approximately 16 percentage points more supportive of abortion than are uninformed respondents. Perhaps more impressively, however, is the effect of information when we compare the non-religious to those claiming a religious affiliation: the informed non-religious are $28 \%$ more likely to support same sex marriage than are the religious, and 34\% more likely to support abortion. These changes in probabilities of support illustrate the 'amplifying' role that information plays, compounded upon what appears to be an already substantial difference along the religious/non-religious divide.

What is also striking, as noted earlier, is the different role that information plays among the non-religious when compared to the effect of information on Catholics. Where information serves to 'bridge' the gap or eliminate the differences between Catholics and non-Catholics for both vote choice and support for same sex marriage, information serves to widen the gap between the religious and non-religious on these same lines. Similarly to the patterns found in the man-woman gap, information appears to play a substantial role in amplifying the differences in choices and attitudes among the religious and non-religious.

\section{Urbanites}

The fourth and final demographic group that was examined included those individuals living in urban versus rural areas, following up on Cutler and Jenkins' (2000) analysis which hinted at the role that education might serve in diminishing the differences between the two 
groups. The data indicate that similarly to the other demographic/social groups, information did indeed affect the nature of opinion and attitudes within these social groups.

Figure 5 illustrates the changes in issue attitudes for uninformed and fully informed urbanites. As the graph demonstrates, information had the largest impact (both substantively and in terms of statistical significance) on two of the dependent variables: support for same sex marriage and closer ties to the United States.

$<$ figure 5 about here $>$

Uninformed urbanites are five percent more likely than their rural counterparts to support same sex marriage, fitting with the notion that individuals living in urban areas are more socially progressive than those in rural areas. With increasing information, the urban/rural gap is widened-information serves to increase the propensity to support same sex marriage among urbanites by approximately five percentage points.

A similar effect occurs on all of the other issues being examined here: fully informed urbanites are six percentage points more likely to support closer ties to the United States than are uninformed urbanites, and information results in a higher probability of support for both doing more for Quebec and easier access to abortion. Simply put, information results in a difference of opinion within the social group. However, it does not appear to reduce the differences between urban and rural dwellers, as we might have expected from Cutler and Jenkins' (2000) analysis. Similarly to the man-woman cleavage, we see an amplification in the differences between the two groups.

\section{Trends Over Time? Modeling the Role of Information, 1988-2004}

The 2004 data suggest that information has a different effect on attitudes for social groups: a 'bridging' effect for some, and an 'amplifying' effect for others. In order to ensure that these results were not simply a 2004 anomaly, the analysis was extended over time. ${ }^{13}$ Data in the 1988, 1993, 1997, and 2000 Canadian Election Studies were recoded, mimicking the recoding method used for 2004. This proved relatively simple for all of the independent variables, but not so simple for the information measure. 
Information levels were measured differently in most of the election studies since 1988, and as a result, some of the years in this analysis employ a slightly different information measure. 2000 comes the closest to the 2004 information measure, as a number of factual questions were also posed in the $2000 \mathrm{CES}$.

In 1993 and 1997 an interviewer rating of political knowledge was included in the study: essentially, at the end of the interview the interviewer was required to assign a value on a scale of 1-5 to the respondent based on how informed or knowledgeable the interviewer felt that respondent to be. This information measure was incorporated into the analysis, rescaled on a 0-1 scale, where 1 represents a very high level of information. This most closely mimics Bartels' (1996) methodology, as it is the measure he used. In addition to Bartels, a number of studies rely upon and point to the utility of this particular measure (see, for example, Luskin 1990; Matthews 2006), thus in absence of factual questions for all years, I am confident in this measure of knowledge or political sophistication seems appropriate.

In 1988, neither factual questions nor an interviewer rating were incorporated into the study, and as a result, an information proxy was employed for this year. An index of 'exposure' was constructed based on two variables: the number of days per week that the individual watched the news on TV and the number of days per week that the individual read the newspaper. Exposure to the news is not exactly the same thing as information or knowledge, and in fact, this measure more closely reflects a 'data-based' understanding of information, as discussed earlier. However, assuming that individuals get their information from the media, this seems like the most appropriate measure given the circumstances, where another measure is simply not available.

Overall, then, this analysis depends on three separate measures of political information, and where possible, attempts were made to ensure that the same measure was employed in two election years in order to boost the level of comparability of one year to the next. ${ }^{14}$ While these indicators are not completely identical, they do represent accepted measures of information in election studies (even longitudinal studies, for example see Matthews 2006) and given the availability of data, represent a reasonable measure of information.

In order to track the effects of information and social group identity on Canadian political attitudes and behaviour over time, the vote choice models (Liberal Party, Progressive Conservative Party, Reform Party, Canadian Alliance Party, and Conservative Party vote choice) 
were re-run for all of those years. Models for the issue areas were not re-run because of changes in the way the questions were asked in the CES over time. Ensuring comparability is a key component of this part of the analysis, and the concern was that attitudes towards these issues could not be tracked consistently over this time period.

For ease of interpretability, Clarify software was again used to determine the effects of information on vote choice for different demographic groups.

\section{Catholics and Vote Choice}

Figure 6 examines the effect of information on the relationship between Catholics and Liberal vote choice. The data support Blais' (2005) observation: Catholics do indeed vote Liberal. Having said that, the data also suggest that uninformed Catholics vote Liberal in much higher proportions than do informed Catholics. In each election year, with the exception of 2000, informed Catholics are at least 15 percentage points less likely than uninformed Catholics to vote Liberal. In 1993 we see the largest information effect, where informed Catholics are over 30 percentage points less likely than uninformed Catholics to vote Liberal.

$<$ figure 6 about here $>$

Both the substantive and statistical significance of these effects strongly suggest that information has the effect of bridging the gap between Catholics and non-Catholics, in much the same way as described by Mendelsohn and Nadeau (1997) in relation to media exposure. Support for the notion that Catholics behave as a voting block is substantially reduced when we consider the role that information plays.

A similar relationship between information and vote choice among Catholics can be seen when we examine vote propensity for the Reform/Alliance/Conservative Party from 1993 to 2004. While vote models for the Progressive Conservative Party during this time period were also run (including 1988), it seems more appropriate to focus on the evolution of support for the newer party, given how much there was to learn, and the potential role that information could have in explaining support for the party. Further, by excluding data from 1988 for the bulk of the analysis, greater uniformity in the information measure is maintained, both conceptually and methodologically. 
As Figure 7 illustrates, uninformed Catholics do not tend to support Reform or the Canadian Alliance, or the new Conservative Party. However, informed Catholics behave quite differently from uninformed Catholics. In every election year except for 2000, informed Catholics are both substantially and significantly more likely to vote for this party than are uninformed Catholics. The 2000 election appears to be an anomaly, and not only among Catholics. This appears to be the case across the board, regardless of social group membership. As the graphs in the following pages illustrate, when more informed, all groups were slightly less likely to vote for the Canadian Alliance. A possible explanation is that informed Catholics were not actually embracing the Liberal Party more than usual, but that instead, this may have been a reaction against Stockwell Day's Canadian Alliance Party. The unusual effects in the 2000 election will be discussed further below.

$<$ figure 7 about here $>$

In every year except for 2000, not only are informed Catholics more likely than uninformed Catholics to vote for the Reform and Conservative Party, but information actually results in a 15 to 20 percentage point jump in support for this party, and the endpoint is a positive coefficient. Thus information has the effect of substantially reducing the gap between Catholics and nonCatholics: it seems that the nature of the Catholic choice varies dramatically by level of information.

\section{Women and Vote Choice}

Consistent with 2004 data, information has the role of widening the gender gap. Women's left-leaning tendencies are strengthened, as they are less likely to support the Reform/Alliance/Conservative Party when they are more informed. Figure 8 illustrates the information effect.

$<$ figure 8 about here $>$

In 1993 we see the biggest information effect, where uninformed women are not very different from uninformed men. Informed women, however, behave quite differently. Information results 
in a 20 percentage point drop, and informed women are approximately $18 \%$ less likely than informed men to vote for Reform. Similar patterns (though less drastic) can be seen for all of the other years as well. 2004 is similar to 1993 in that uninformed women are no different from uninformed men in their propensity to vote for the Conservative Party. Information results in a near ten percentage point drop, as informed women are less likely to support the Conservatives. ${ }^{15}$

\section{Urbanites and Vote Choice}

Urbanites, like women, tend to be slightly more left-leaning than those living in rural areas. As such, they tend not to support the right. Having said that, the data indicate that information does indeed play a role in minimizing the urban/rural gap. Figure 9 illustrates the effect of information on Reform/Alliance/Conservative Party vote propensity among urbanites. In 1993 and 2000, the line is nearly flat, indicating that those who were more informed did not really behave differently than those who were less informed. This may be a reflection of the availability of information itself: in 1993, the Reform Party was relatively new, and not a lot of information was held about the party. One might expect that as people learned more (over time), information might have a larger effect.

$<$ figure 9 about here $>$

Indeed, this theory is supported if we look at the other lines. In 1997, when people knew more about the Reform Party in general, those who were more informed tended to be more open to the Party. This is not to say that they were supporting the Party (the trend lines are all below zero), but information did actually reduce the difference between urban and rural voters. In 2000, the Reform Party had evolved into the Canadian Alliance, with a new leader. This may have resulted in a move back to 'square one' for the Canadian public: they knew little about what this new party was all about, thus leaving little difference between individuals with higher levels of general political knowledge and those with low levels of political knowledge. Indeed, for all social groups, the line for support for Reform/Alliance support in 2000 is nearly flat, suggesting that information/knowledge did not have a major role, and where it did, it resulted in a slight drop in the probability of support for Alliance. The data support the notion that because the Party 
was so new, there wasn't much to be learned yet about the Party, and what little information there was didn't paint the Party in a positive light.

In 2004, the Party changed again, but this time merging with the old Progressive Conservative Party, a party that had existed since Confederation, and which voters were likely to be more familiar with. This may have generated room for information to play a role, as individuals who were more informed in general may also have been more informed about this Party in particular. In fact, as the bottom-most line indicates, information resulted in a 15 percentage point rise, substantially reducing the difference between urban and rural voters. Informed urban voters were still less likely to vote for the Conservative Party than were informed rural voters (by approximately $8 \%$ ), but this was very different from the $20 \%$ difference between uninformed urban and rural voters.

The bridging effect that information appears to have among rural and urban voters in relation to vote choice contrasts with the amplifying effect it has with regards to issue attitudes, suggesting that information may play a different type of role in different circumstances. One could surmise that perhaps vote choice or party support is inherently different from attitudes towards specific issues: Canadian brokerage parties appeal to different groups for different reasons (or even the same group for different reasons), and information may tap into group values in slightly different ways. More research is needed to fully understand these effects.

\section{The Non-Religious and Vote Choice}

The effect of information on vote choice among the non-religious closely resembles that among women, in that it serves to strengthen group attitudes. As Figure 10 illustrates, information results in a decrease in support for the Reform/Alliance/Conservative Party within this group, and it increases the gap between the non-religious and those claiming religious affiliation.

$<$ figure 10 about here $>$

In nearly all of the election years being examined, information results in a 10-15 percentage point decrease in propensity among the non-religious to support the Party. At the $95 \%$ confidence level, the differences are significant for most of the information range, suggesting 
that information not only plays a pivotal role in informing the vote choice of Catholics, but that it also substantially affects the nature of party support among the non-religious. The effect of information within this group as illustrated above is ideologically consistent with the effect of information on support for both same sex marriage and abortion: the informed non-religious appear to be more left-leaning and socially progressive than both respondents with a religious affiliation, as well as the less-informed non-religious. Information strengthens the attitudes within this social group, rather than diminishing them as it did for Catholics and urbanites.

\section{Discussion}

Overall, these results are consistent with Bartels' study: less informed voters do not behave as if they were more informed, either in terms of vote choice or issue attitudes. The persistence of trend lines and the magnitudes of differences indicate that information has an important mediating effect on issue attitudes, regardless of whether the issue has been around for quite some time (ties to the United States and abortion), or has only more recently entered public debate (same sex marriage). More importantly, not only do the less informed not behave like the more informed, but information also has important and discernible effects on the influence of social group identity in forming preferences. For example, with higher levels of information, Catholics are less likely to support the Liberal Party.

There is a substantial literature examining the decision-making abilities of citizens given how little information or knowledge is possessed by the average citizen. Important research in this literature has suggested that citizens will use information shortcuts or heuristics to overcome the information deficit, and that even if individuals don't have a lot of information, they are still able to use what information and tools they do have to come to reasoned decisions - often the same decisions they would come to if they had more information (Brady and Sniderman 1985; Lau and Redlawsk 1997). Sniderman et al. (1991) point to the role of the social group as an intermediary: group membership and group affect help individuals to come to the same decisions they would make if they were fully informed.

In the general population, there is indeed a group basis of attitude and opinion: women often hold attitudes different from those of men, 'Catholics vote Liberal,' rural folk tend to be more socially/morally conservative than those living in urban areas. However, as the data from 
the 1988 to 2004 CES illustrate, for some groups, information plays an important role in 'bridging' that cultural divide. Informed urbanites tend to be less different from their rural counterparts with respect to vote choice. Information helps to (dramatically) reduce the difference between Catholics and non-Catholics in terms of both vote choice as well as support for same sex marriage. These data indicate, therefore, that social group identity is not a way to bring the less informed 'up' to the point they would be at if they were more informed, as suggested by some scholars. Instead, the more informed and less informed members of a given social group simply behave differently.

The integration of information levels into the relationship between social group identity and political attitudes is particularly important in the Canadian case, given the extent to which the Canadian literature has focused on the long-standing 'differences' between particular social groups - in particular, Catholics vs. Protestants and the urban/rural divide - without being able to concretely suggest why this is so. Johnston (1985) suggests that the Catholic/Protestant difference is grounded in identification with and socialization into the social group, and the CES data do indeed provide support for that hypothesis, indicating that these traditional group-based attitudes are not necessarily related to group-based 'interests.' Further, we see evidence that as individuals become more informed, they appear to lose reliance upon that social group identity in informing their attitudes and making choices. In a sense, information level trumps identification with the social group.

\section{Two "kinds" of social cleavages?}

While the data indicate that information has a 'bridging' effect among some social groups (namely Catholics/non-Catholics and urban/rural — in terms of vote choice in the latter), it also appears to have an 'amplifying' effect along other cleavage lines. Among women and the nonreligious in particular, information had the opposite effect: the less informed behave less 'differently' than the reference groups (men and those claiming some religious affiliation). In the simulation exercise, with increased levels of information, 'social group' behaviour became increasingly pronounced, with groups becoming more left-leaning and socially 'progressive' than the reference groups. In effect, group differences were accentuated or amplified.

These results raise a number of questions about the nature of social group values. Do some values exist and flourish largely as a result of a basic form of identification or 'group think' 
regardless of whether the attitudes are in the group's 'interest,' only to diminish when people become more informed, while other values lay dormant among the general (uninformed) population but become more pronounced as individuals become more aware of their self or group-interest? Furthermore, what is to become of these social cleavages in the future, with the ever-growing increase in the education of the mass-public? Do the traditional religious and urban/rural cleavages have the potential to all but disappear as the population becomes even more educated and informed in the future? More research is needed into the linkages between information and social group identities and values if we are to better understand the nature of social cleavages in Canada, and the impact they may have on public opinion and electoral outcomes.

\footnotetext{
${ }^{1}$ For example, some have suggested that these cleavages are a result of historical and cultural roots that have been passed down for generations (Horowitz 1966; Irvine and Gold 1980). Others have suggested that Canadian institutions have had a major role in perpetuating and exacerbating social cleavages (Cairns 1968; Cairns 1977). ${ }^{2}$ The data for the 1988-2004 CES were collected by the Institute for Social Research for the research teams: in 1988, the Team included Richard Johnston, André Blais, Henry E. Brady, and Jean Crete. In 1993, the Team included Richard Johnston, André Blais, Henry E. Brady, Elisabeth Gidengil, and Neil Nevitte. In 1997 and 2000 the Team included André Blais, Elisabeth Gidengil, Neil Nevitte, and Richard Nadeau. In 2004, the Team included André Blais, Joanna Everitt, Patrick Fournier, Elisabeth Gidengil, and Neil Nevitte.

3 See, for example, Rand Dyck. 2000. Canadian Politics: Critical Approaches, 3rd Edition. Scarborough, Nelson Thomson Learning; and Keith Archer, Roger Gibbins, Rainer Knopff, Heather MacIvor, and Leslie A. Pal. 2002. Parameters of Power: Canada's Political Institutions, 3rd Edition. Scarborough, Thomson Nelson Learning. 4 To use a phrase employed as a title: Lupia and McCubbins (1998).

${ }^{5}$ Simply put, it would be inappropriate to examine the attitudes and opinions of those within and outside of Quebec in the same model. They must be modeled separately. This study separates the two groups, and due to space limitations, this study is limited to voters outside of Quebec. While it does not claim to extend its conclusions to Quebec, there is no reason to believe that the dynamic between the less informed and more informed individuals within social groups would not be replicated among the Quebecois as well. Future research on this topic should extend its analysis to Quebec, in order to provide a fuller picture of the relationship between social cleavages and information.

6 The STATA command for this process is "lincom." In Tables 1 and 2, fully informed preferences reflect the linear combination of the coefficient of the demographic variable and the coefficient of the related interacted term.

${ }^{7}$ An exploratory model was run with partisanship included. Its inclusion resulted in an increase in the multicollinearity in the model. The inclusion of Party Identification also had the further effect of boosting the size of the coefficients - the effect of information was more pronounced when partisanship was controlled for. As a result, it seemed appropriate to stick with a model with less multicollinearity, particularly when this model produced more conservative estimates.

${ }^{8}$ Bartels provides the basis for this analysis, and for further discussion about the exclusion of highly proximate variables, see page 208 of his (1996) article.

9 Estimations of all other models are available from the author upon request.

10 Tomz, Wittenberg, and King have argued that "even coefficients that are not statistically significant can provide important information: after all, a coefficient that is not statistically significant from zero will probably significantly different [sic] from almost all other numbers" (2003:19). In this study, the statistical output was examined to look at both standard errors and confidence intervals (at both the 90th and 95th percentiles) to ensure that the observable patterns were not simply random. In the bulk of cases, the reported means of first differences were at least or nearly twice the size of the standard errors, and in those situations where they were not, the confidence intervals tended not to straddle zero.
} 
11 This is not to suggest that being non-religious means an individual is an atheist. In the 2004 CES, respondents claiming to be atheists or to have no religion were categorized together, and a separate category was created for those claiming to be agnostic. In 1988, the category was "no religion," and in 1993-2000 the category was "none." 12 In fact, the proportion of atheists/non-religious individuals in comparison to Protestants and Catholics appears to have increased over time: the proportion of non-religious in the total sample increased from $14 \%$ in 1997 to $15 \%$ in 2000 to $18 \%$ in 2004 .

13 I would like to thank Francois Pétry for his comments and suggestions which led to this further analysis.

${ }^{14}$ In 1997, the option of analyzing the data using a knowledge index based on factual questions was available again, but the analysis was instead based on the interviewer rating to ensure that 1993 was not the only year for which an interviewer rating was used. In fact, when I ran the model using the knowledge index for 1997 rather than the interviewer rating, the results were quite similar.

15 In fact, of all of those who admitted to voting for the Conservative Party in the 2004 CES, 52\% were women and $48 \%$ were men. Furthermore, there were fewer women in the higher end of the knowledge index, providing further suggestion that the bulk of the female vote for the Conservative vote came from less informed women. 
Table 1

Conservative Party Vote Propensity (ROC), 2004

\begin{tabular}{|c|c|c|c|}
\hline & $\begin{array}{l}\text { Fully Informed } \\
\text { Preferences }\end{array}$ & $\begin{array}{l}\text { Uninformed } \\
\text { Preferences }\end{array}$ & $\begin{array}{c}\text { Information } \\
\text { Effect } \\
\text { (Difference) }\end{array}$ \\
\hline \multirow[t]{2}{*}{ Intercept } & 0.060 & -0.570 & 0.630 \\
\hline & $(0.427)$ & $(0.440)$ & $(0.758)$ \\
\hline \multirow[t]{2}{*}{ Age } & -0.008 & 0.011 & -0.019 \\
\hline & $(0.007)$ & $(0.007)$ & $(0.012)$ \\
\hline \multirow[t]{2}{*}{ Education } & -0.083 & 0.042 & -0.126 \\
\hline & $(0.071)$ & $(0.086)$ & $(0.140)$ \\
\hline \multirow[t]{2}{*}{ Income } & 0.012 & 0.010 & 0.001 \\
\hline & $(0.028)$ & $(0.032)$ & $(0.053)$ \\
\hline \multirow[t]{2}{*}{ Woman } & -0.190 & 0.032 & -0.222 \\
\hline & $(0.142)$ & $(0.167)$ & $(0.277)$ \\
\hline \multirow[t]{2}{*}{ Married } & 0.394 & 0.115 & 0.279 \\
\hline & $(0.166)^{* *}$ & $(0.174)$ & $(0.303)$ \\
\hline \multirow[t]{2}{*}{ Urban } & -0.206 & -0.559 & 0.354 \\
\hline & $(0.157)$ & $(0.172)^{* * *}$ & $(0.296)$ \\
\hline \multirow[t]{2}{*}{ Atlantic } & -0.213 & -0.381 & 0.168 \\
\hline & $(0.251)$ & $(0.263)$ & $(0.461)$ \\
\hline \multirow[t]{2}{*}{ Prairies } & 0.508 & 0.425 & 0.083 \\
\hline & $(0.173)^{* * *}$ & $(0.200)^{* *}$ & $(0.334)$ \\
\hline \multirow[t]{2}{*}{$\mathrm{BC}$} & 0.346 & -0.016 & 0.362 \\
\hline & $(0.191)^{*}$ & $(0.227)$ & $(0.373)$ \\
\hline \multirow[t]{2}{*}{ Catholic } & 0.053 & -0.718 & 0.771 \\
\hline & $(0.178)$ & $(0.201)^{* * *}$ & $(0.340)^{* *}$ \\
\hline \multirow[t]{2}{*}{ Atheist } & -0.705 & -0.115 & -0.590 \\
\hline & $(0.178)^{* * *}$ & $(0.203)$ & $(0.338)^{*}$ \\
\hline \multirow[t]{2}{*}{ Retired } & 0.226 & -0.077 & 0.303 \\
\hline & $(0.248)$ & $(0.312)$ & $(0.506)$ \\
\hline \multirow[t]{2}{*}{ Self Employed } & 0.317 & 0.001 & 0.316 \\
\hline & $(0.213)$ & $(0.286)$ & $(0.453)$ \\
\hline \multirow[t]{2}{*}{ Native French Speaker } & 0.200 & -0.532 & 0.732 \\
\hline & $(0.375)$ & $(0.446)$ & $(0.729)$ \\
\hline
\end{tabular}

Log Likelihood $=-975.680 \mathrm{~N}=1593$

Standard errors in parentheses

$*$ significant at $10 \% ; * *$ significant at $5 \% ; * * *$ significant at $1 \%$ 
Table 2

Support for Same Sex Marriage (ROC), 2004

\begin{tabular}{|c|c|c|c|}
\hline & $\begin{array}{l}\text { Fully Informed } \\
\text { Preferences }\end{array}$ & $\begin{array}{l}\text { Uninformed } \\
\text { Preferences }\end{array}$ & $\begin{array}{c}\text { Information } \\
\text { Effect } \\
\text { (Difference) }\end{array}$ \\
\hline Intercept & $\begin{array}{l}-0.139 \\
(0.436)\end{array}$ & $\begin{array}{l}-0.109 \\
(0.448)\end{array}$ & $\begin{array}{l}-0.030 \\
(0.767)\end{array}$ \\
\hline Age & $\begin{array}{c}-0.021 \\
(0.007)^{* * *}\end{array}$ & $\begin{array}{c}-0.025 \\
(0.007)^{* * *}\end{array}$ & $\begin{array}{c}0.004 \\
(0.013)\end{array}$ \\
\hline Education & $\begin{array}{c}0.176 \\
(0.073)^{* *}\end{array}$ & $\begin{array}{l}-0.011 \\
(0.089)\end{array}$ & $\begin{array}{c}0.187 \\
(0.143)\end{array}$ \\
\hline Income & $\begin{array}{c}0.019 \\
(0.029)\end{array}$ & $\begin{array}{c}0.016 \\
(0.033)\end{array}$ & $\begin{array}{c}0.003 \\
(0.055)\end{array}$ \\
\hline Woman & $\begin{array}{c}0.567 \\
(0.146)^{* * *}\end{array}$ & $\begin{array}{c}0.441 \\
(0.182)^{* *}\end{array}$ & $\begin{array}{c}0.126 \\
(0.292)\end{array}$ \\
\hline Married & $\begin{array}{c}-0.456 \\
(0.170)^{* * *}\end{array}$ & $\begin{array}{c}0.086 \\
(0.179)\end{array}$ & $\begin{array}{c}-0.542 \\
(0.309)^{*}\end{array}$ \\
\hline Homeowner & $\begin{array}{c}0.192 \\
(0.197)\end{array}$ & $\begin{array}{l}-0.249 \\
(0.198)\end{array}$ & $\begin{array}{c}0.441 \\
(0.347)\end{array}$ \\
\hline Urban & $\begin{array}{c}0.277 \\
(0.163)^{*}\end{array}$ & $\begin{array}{c}0.165 \\
(0.179)\end{array}$ & $\begin{array}{c}0.111 \\
(0.306)\end{array}$ \\
\hline Atlantic & $\begin{array}{c}0.741 \\
(0.239)^{* * *}\end{array}$ & $\begin{array}{l}-0.264 \\
(0.262)\end{array}$ & $\begin{array}{c}1.005 \\
(0.446)^{* *}\end{array}$ \\
\hline Prairies & $\begin{array}{c}-0.494 \\
(0.184)^{* * *}\end{array}$ & $\begin{array}{l}-0.254 \\
(0.214)\end{array}$ & $\begin{array}{l}-0.240 \\
(0.355)\end{array}$ \\
\hline $\mathrm{BC}$ & $\begin{array}{c}0.029 \\
(0.192)\end{array}$ & $\begin{array}{l}-0.074 \\
(0.231)\end{array}$ & $\begin{array}{c}0.103 \\
(0.376)\end{array}$ \\
\hline Catholic & $\begin{array}{c}0.010 \\
(0.186)\end{array}$ & $\begin{array}{l}-0.274 \\
(0.214)\end{array}$ & $\begin{array}{c}0.284 \\
(0.357)\end{array}$ \\
\hline Atheist & $\begin{array}{c}0.775 \\
(0.171)^{* * *}\end{array}$ & $\begin{array}{c}0.529 \\
(0.201)^{* * *}\end{array}$ & $\begin{array}{c}0.246 \\
(0.329)\end{array}$ \\
\hline Retired & $\begin{array}{l}-0.223 \\
(0.253)\end{array}$ & $\begin{array}{c}0.065 \\
(0.349)\end{array}$ & $\begin{array}{l}-0.288 \\
(0.542)\end{array}$ \\
\hline Self Employed & $\begin{array}{l}-0.198 \\
(0.207)\end{array}$ & $\begin{array}{c}0.465 \\
(0.262)^{*}\end{array}$ & $\begin{array}{l}-0.663 \\
(0.420)\end{array}$ \\
\hline Native French Speaker & $\begin{array}{c}0.270 \\
(0.386)\end{array}$ & $\begin{array}{l}-0.164 \\
(0.441)\end{array}$ & $\begin{array}{c}0.434 \\
(0.725)\end{array}$ \\
\hline
\end{tabular}

Log Likelihood $=-877.42742 \quad \mathrm{~N}=1746$

Standard errors in parentheses

* significant at $10 \%$; * significant at $5 \%$; ** significant at $1 \%$ 
Table 3

Number of individuals claiming to be Atheist, Catholic, or

Protestant in 2004 CES

\begin{tabular}{lcccc}
\hline & \multicolumn{2}{c}{ Voters } & \multicolumn{2}{c}{ Total Sample } \\
\hline & $\#$ & $\%$ & $\#$ & $\%$ \\
Atheists & 507 & 18.65 & 783 & 18.11 \\
Catholics & 974 & 35.82 & 1670 & 38.63 \\
Protestants & 730 & 26.85 & 1056 & 24.43 \\
\hline All & 2719 & 100 & 4323 & 100 \\
\hline
\end{tabular}


Figure 1

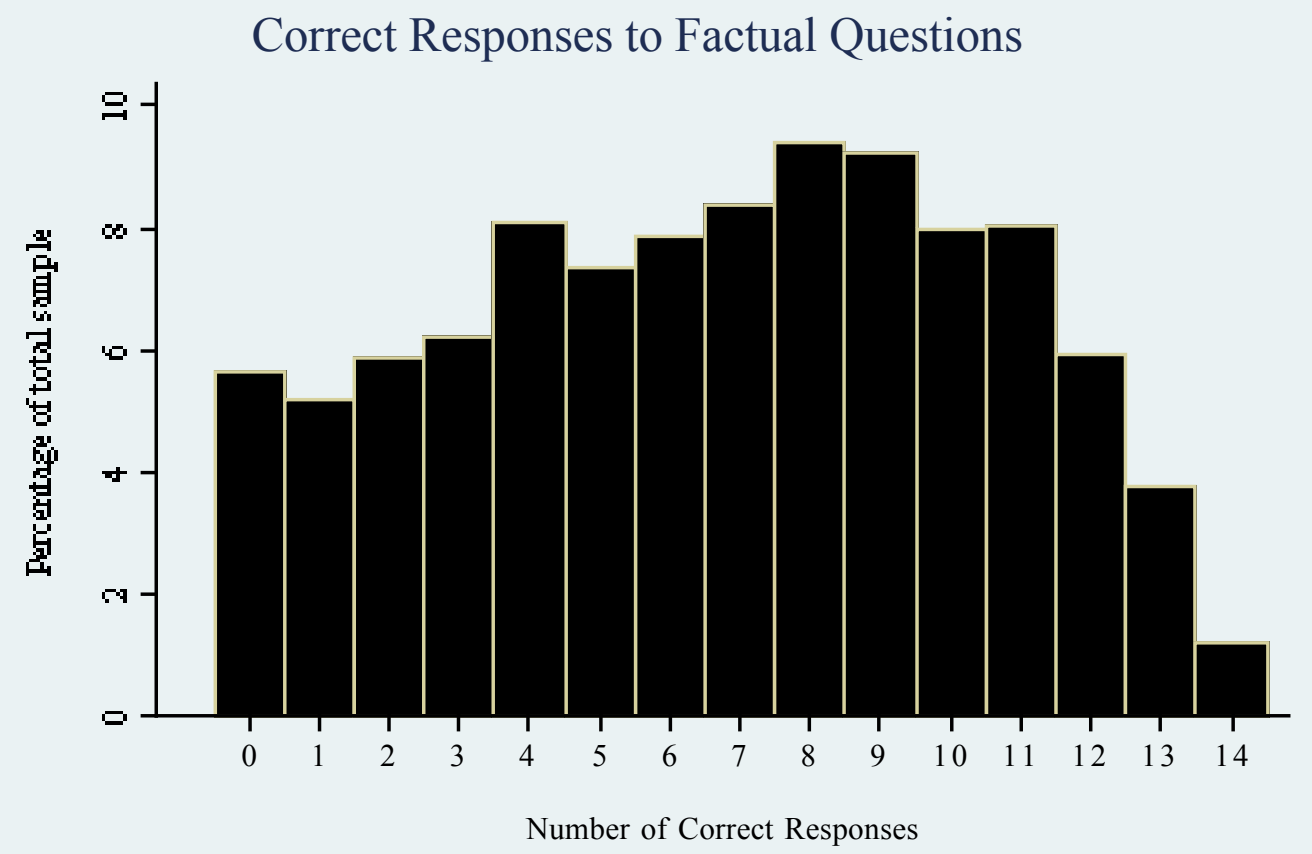


Figure 2

Catholics and Issue Attitudes (2004)
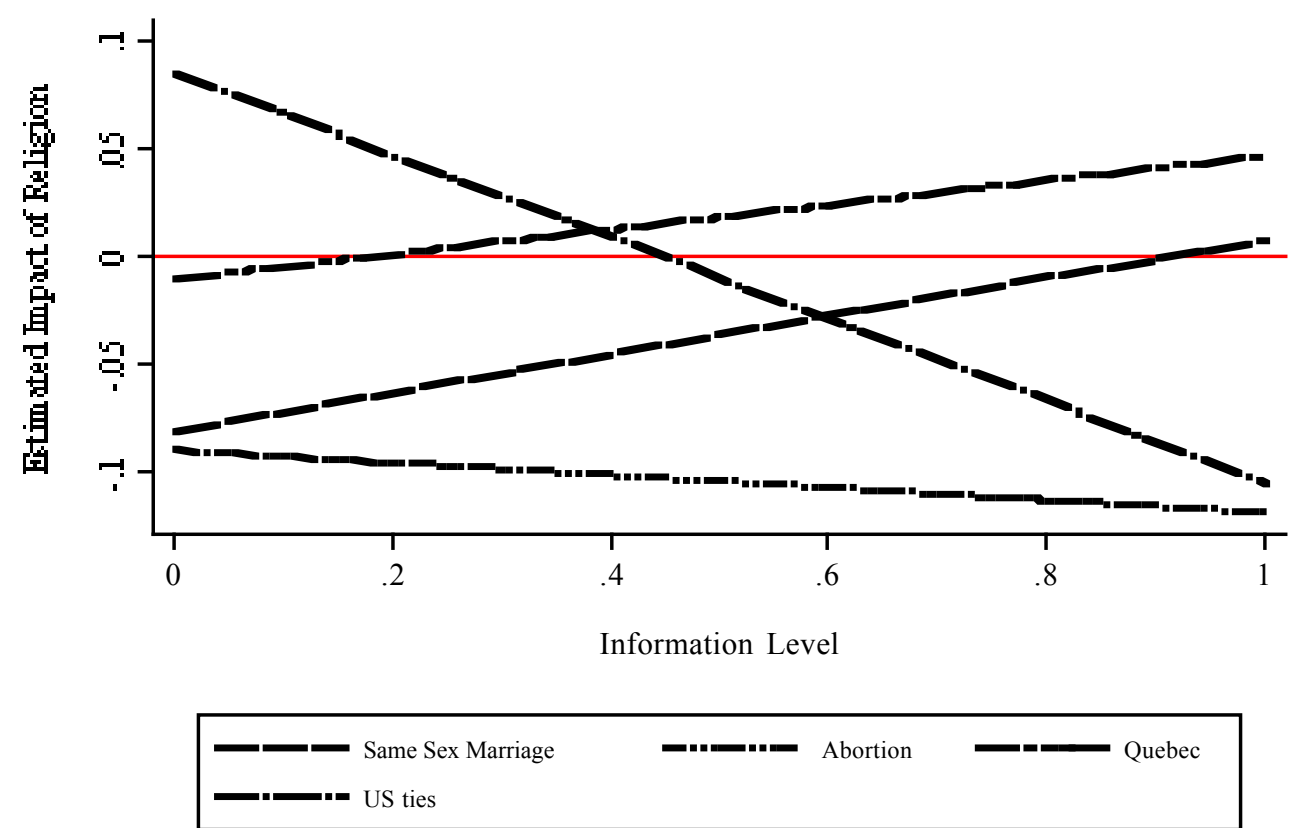

Figure 3

Women and Issue Attiudes (2004)

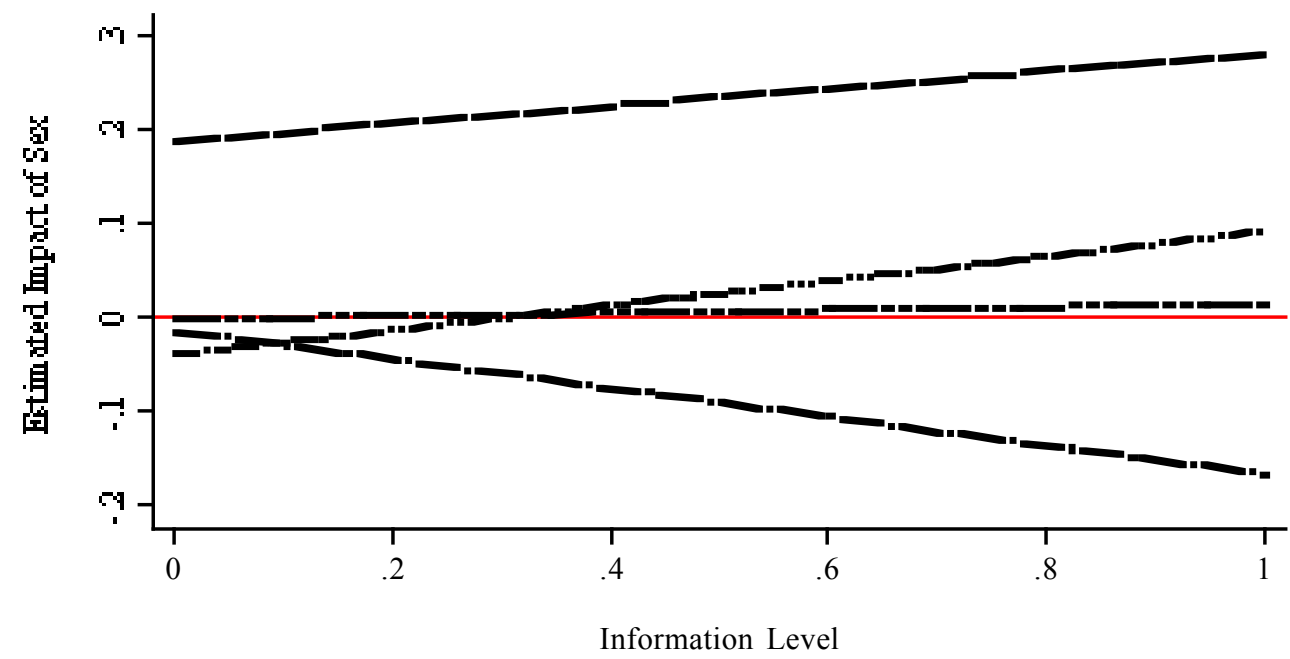

$\begin{array}{ll}\text { Same Sex Marriage } & \text { Abortion } \\ & \text { US ties }\end{array}$


Figure 4

Non-Religious and Issue Attitudes (2004)

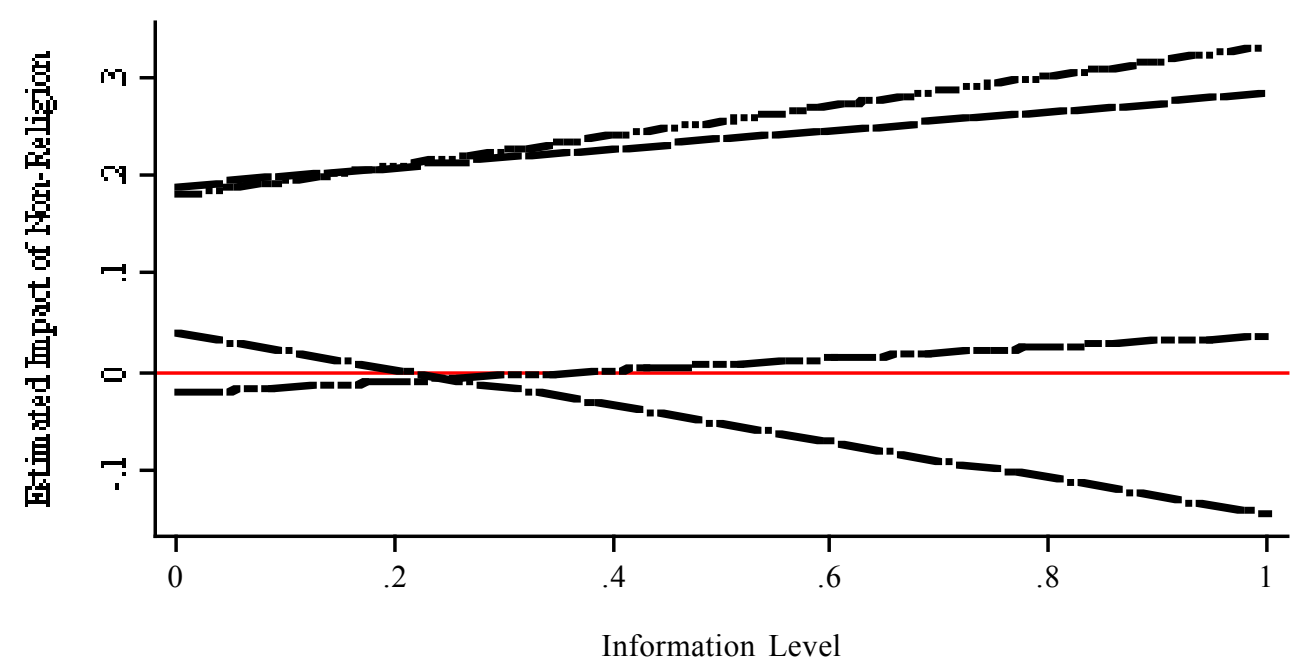

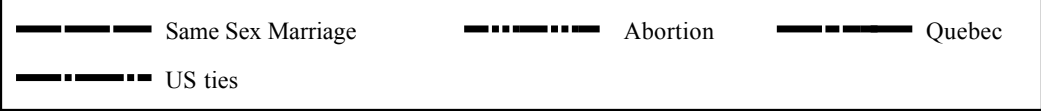

Figure 5

Urbanites and Issue Attitudes (2004)

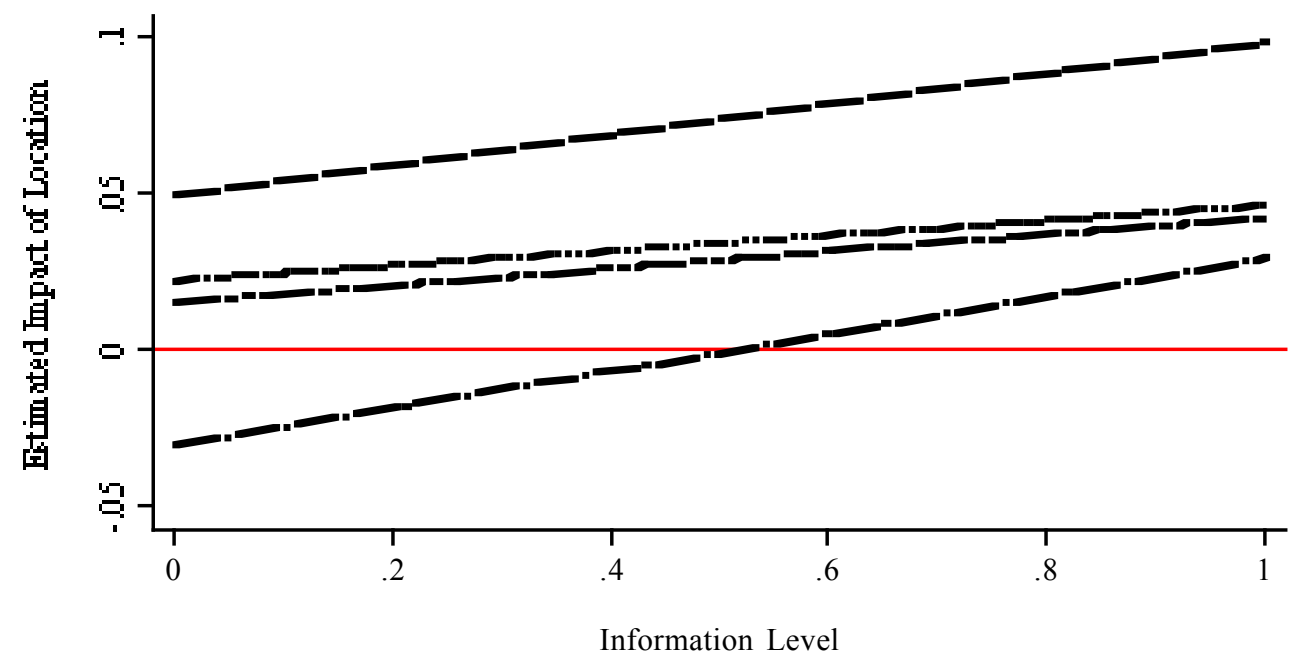

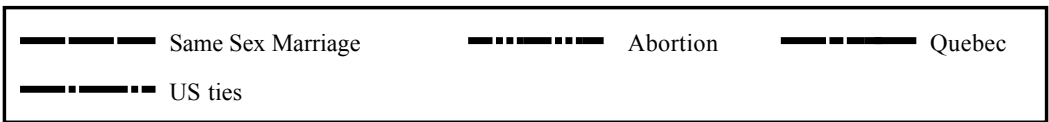


Figure 6

Catholics and the Liberal Vote

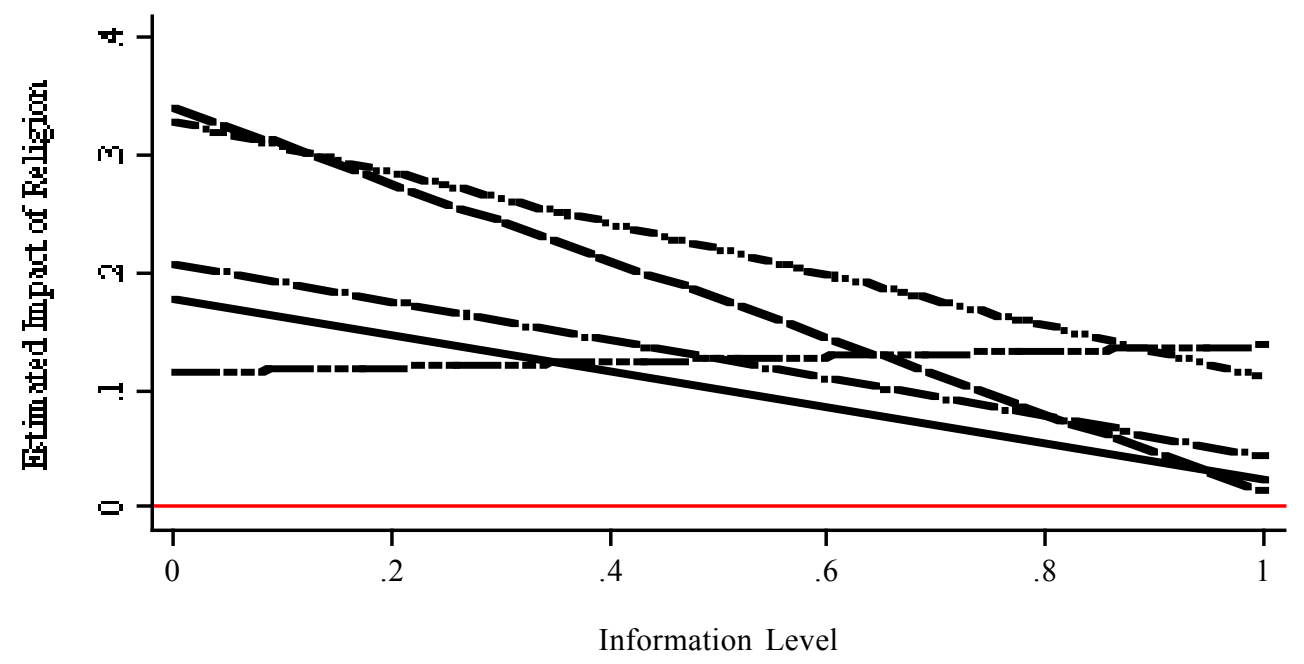

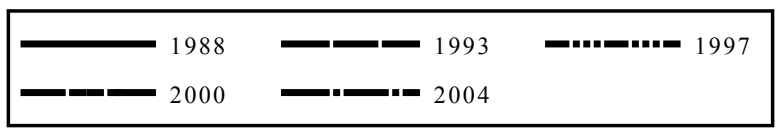

Figure 7

Catholics and the Reform/Alliance/Conservative Vote

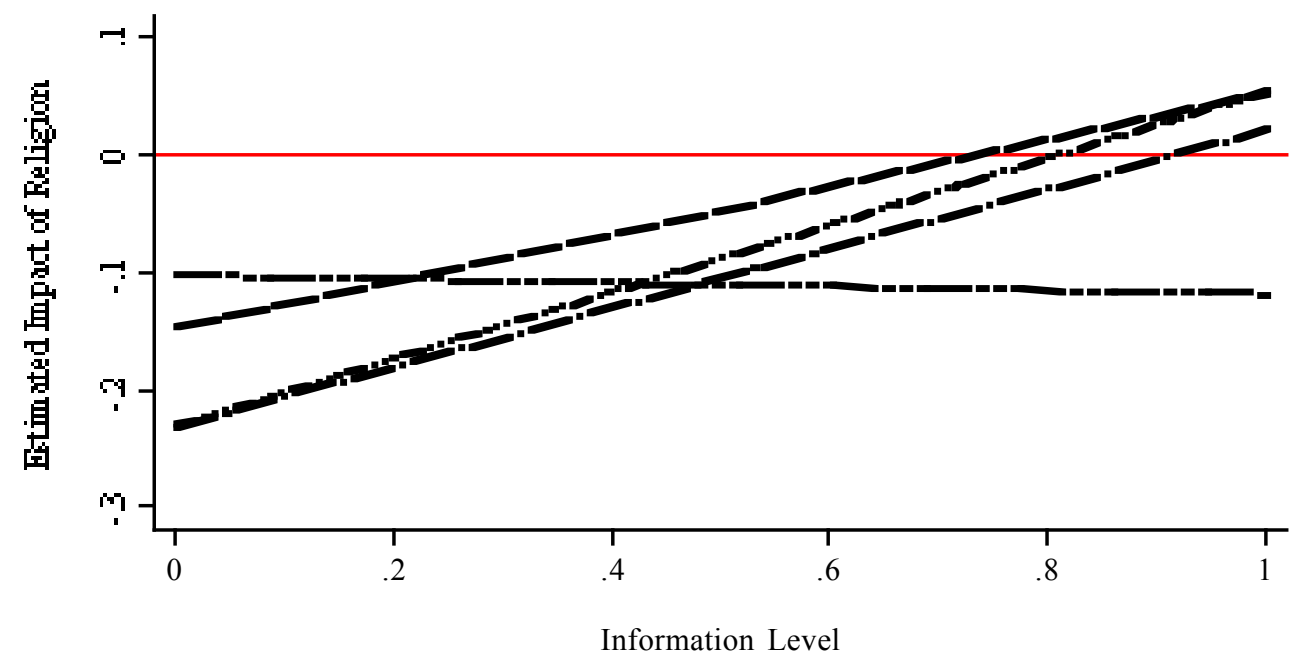

\begin{tabular}{|lll|}
\hline - 1993 & & \\
2004 & &
\end{tabular}


Figure 8

Women and the Reform/Alliance/Conservative Vote
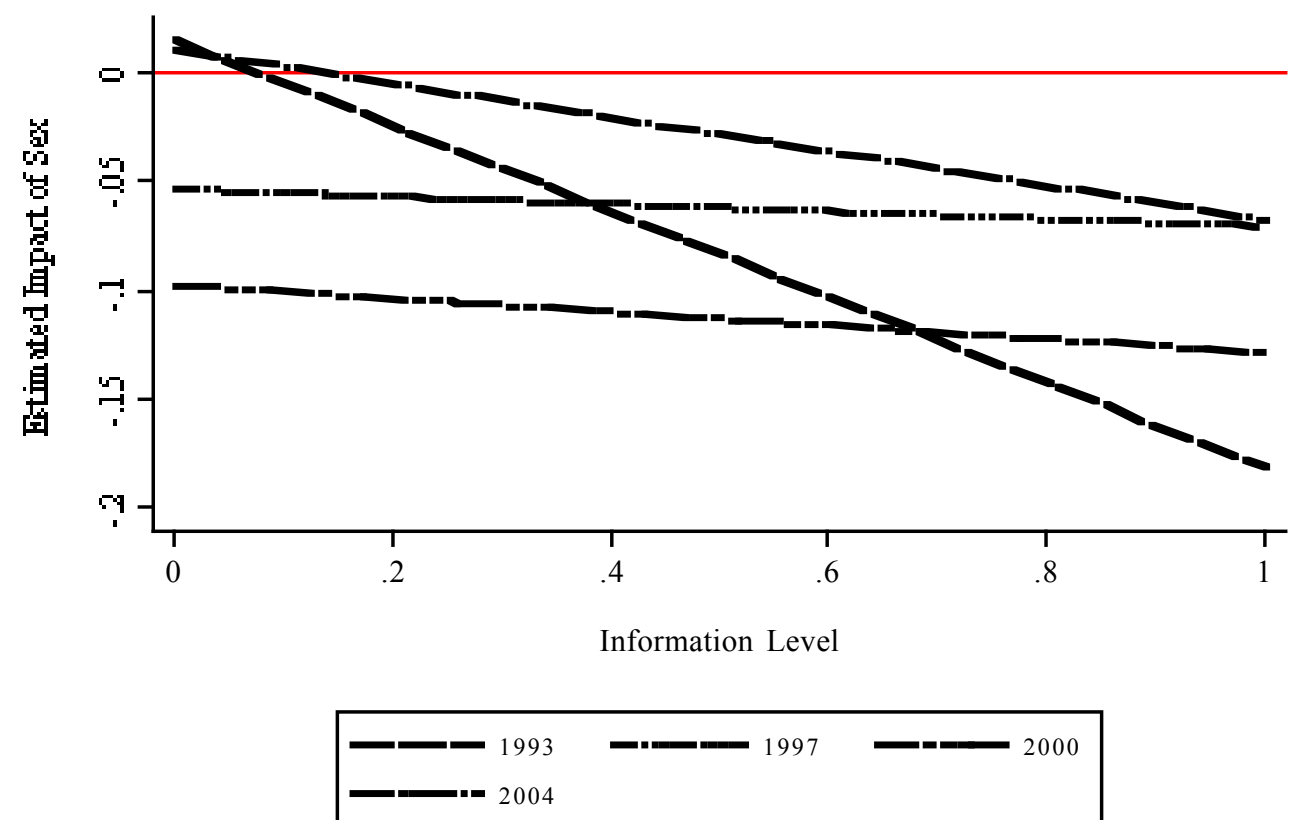

Figure 9

Urbanites and the Reform/Alliance/Conservative Vote

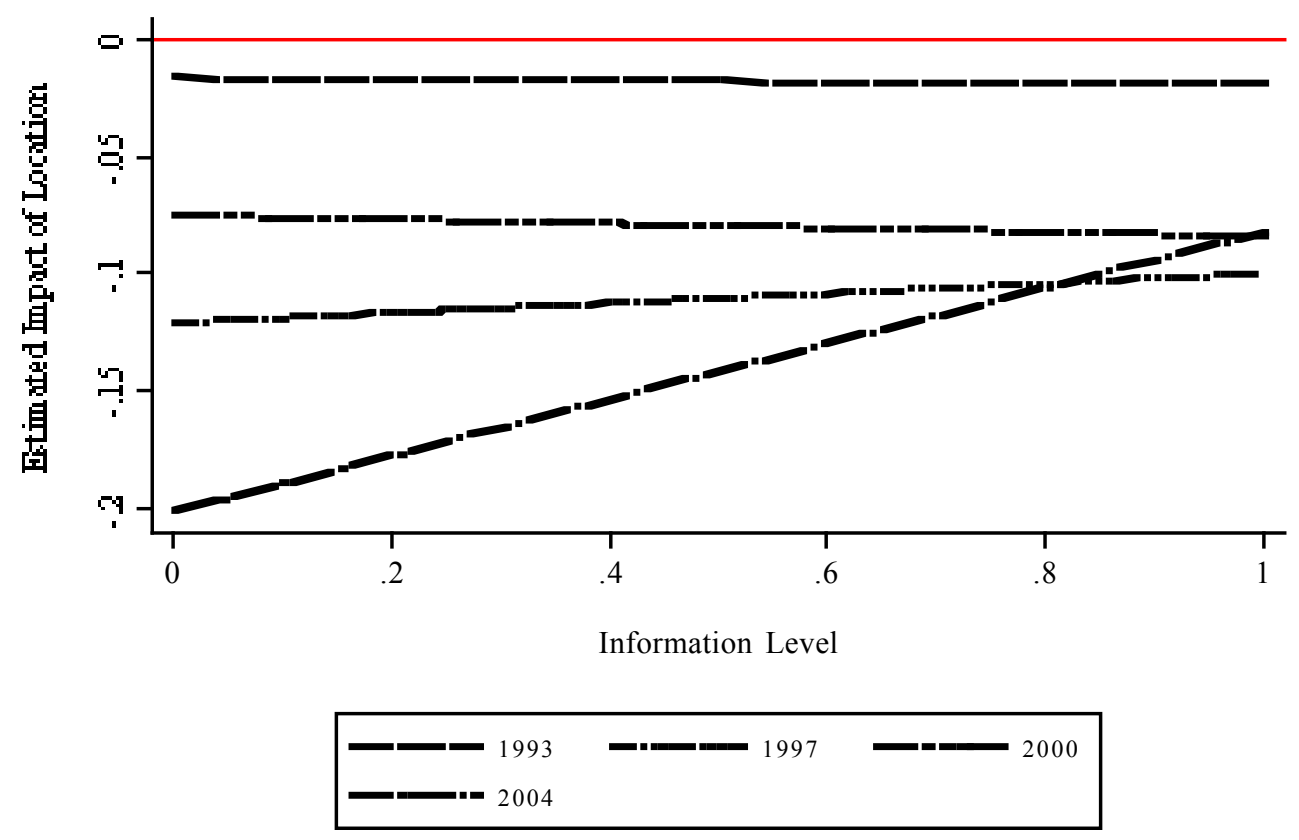


Figure 10

The Non-Religious and the Reform/Alliance/Conservative Vote

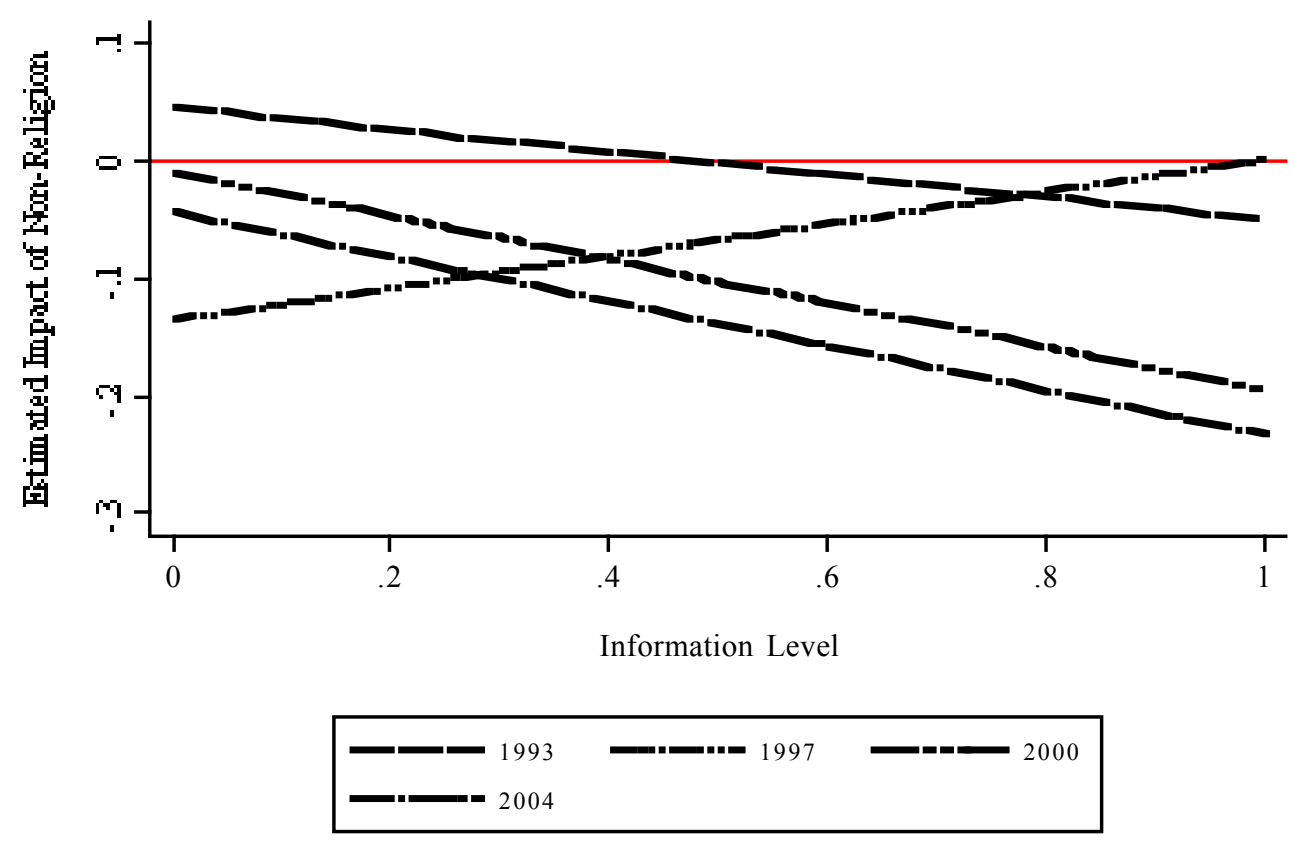




\section{Appendix: Variable Definitions}

\section{Political Knowledge}

CES 2004

Index built based on correct responses to 14 factual questions:

KNOW1 - recall name of leader of the Federal NDP (Jack Layton)

KNOW2 - recall name of leader of the Federal Conservative Party (Stephen Harper)

KNOW3 - recall name of leader of the Federal Liberal Party (Paul Martin)

KNOW4 - recall which party was promising to get rid of the Gun Registry (Conservatives)

KNOW5 - recall name of party promising to get rid of sales tax on family essentials (NDP)

KNOW6 - party promising to increase military spending by $\$ 2$ billion (Conservatives)

KNOW7 - party promising \$250 million spending on AIDS in poor countries (Liberals)

KNOW8 - party promising $\$ 4$ billion to reduce wait times for surgeries (Conservatives)

KNOW9 - party promising inheritance tax on estates over \$1 million (NDP)

KNOW10 - recall name of respondent's provincial Premier

KNOW11 - recall name of Federal Finance Minister (Ralph Goodale)

KNOW12 - recall name of British Prime Minister (Tony Blair)

KNOW13 - recall name of female cabinet minister who ran against Paul Martin for Liberal Party leadership (Sheila Copps)

KNOW14 - know which level of government is responsible for healthcare, etc. (Provincial)

All recoded as 0-1 dummy, where 1=correct answer. Added together to form index, then recoded on a $0-1$ scale where $1=$ correct responses to all 14 questions, $0=$ no correct responses at all. DK coded as 0 , Ref coded as missing.

\section{CES 2000}

Index built based on correct responses to 11 factual questions: 
KNOW1 - recall name of Provincial Premier

KNOW2 - recall name of Finance Minister of Canada (Paul Martin)

KNOW3 - recall name of PM at the time of Free Trade Agreement with US (Brian Mulroney)

KNOW4 - recall name of the capital city of United States (Washington DC)

KNOW5 - recall which party is saying that high taxes have produced a brain drain from Canada to the US (Alliance)

KNOW6 - recall which party is saying that tougher sentences will NOT reduce youth violence (Bloc \& NDP)

KNOW7 - recall which party promised a single tax rate for people earning less than one hundred thousand dollars a year (Alliance)

KNOW8 - recall which party proposed a national prescription drug plan (NDP)

KNOW9 - recall which party promised a law to fight criminal biker gangs (Bloc \& Alliance)

KNOW 10 - recall which party proposed a law to pay back the debt in 25 years (Conservatives)

KNOW11 - recall which party promised to use HALF of the surplus to cut taxes and pay down the debt and HALF to spend on health care and social programs (Liberals)

All recoded as 0-1 dummy, where $1=$ correct answer. Added together to form index, then recoded on a $0-1$ scale where $1=$ correct responses to all 11 questions, $0=$ no correct responses at all. DK coded as 0 , Ref coded as missing.

CES 1997

Knowledge level evaluated and assigned by interviewer at time of interview. 5 levels rescaled on $0-1$ scale where 0 represents very low level of knowledge and 1 represents very high level of knowledge.

\section{CES 1993}

Knowledge level evaluated and assigned by interviewer at time of interview. 5 levels rescaled on $0-1$ scale where 0 represents very low level of knowledge and 1 represents very high level of knowledge.

\section{CES 1988}


Index based on two variables (no knowledge measures included in survey): number of days/week watched news on TV + number of days/week read newspaper.

Combined and rescaled to $0-1$ scale, where 0 represents no attention to news on either TV or newspaper, and 1 represents 7 days of both TV and newspaper attention. DK/Ref coded as missing.

\section{Issue Attitudes}

FAVOURSAMESEXMAR - Based on: "Do you favour or oppose same-sex marriage, or do you have no opinion on this?" Recoded as a dummy variable, $1=$ favour; $0=$ all others. DK/Ref coded as missing.

ABORTION - Based on: "Do you think it should be: very easy for women to get an abortion, quite easy, quite difficult, or very difficult?" Recoded as a dummy variable, $1=$ very easy/quite easy; $0=$ all others. DK/Ref coded as missing.

DOMOREFORPQ - Based on: "How much do you think should be done for Quebec: much more, somewhat more, about the same as now, somewhat less, or much less?" Recoded as a dummy variable, $1=$ more/somewhat more; $0=$ all others. DK/Ref coded as missing.

PROCLOSETIESUS - Based on: "Do you think Canada's ties with the United States should be much closer, somewhat closer, about the same as now, more distant or much more distant?" Recoded as a dummy variable, 1= more/somewhat closer; $0=$ all others. DK/Ref coded as missing.

\section{Demographic Variables}

AGE - from year of birth

EDUCATION - coded into 5 categories: $1=$ elementary school or less $2=$ high school or less $3=$ some college/some university $4=$ completed college/completed university $5=$ post-graduate/professional. DK/Ref coded as missing.

INCOME - coded into 10 categories: $1<\$ 20,0002 \$ 20-29,9993 \$ 30-39,9994 \$ 40$ 49,999 $5 \$ 50-59,9996 \$ 60-69,9997 \$ 70-79,9998 \$ 80-89,9999$ \$90-99,999 10 $\$ 100,000+$. DK/Ref coded as missing.

WOMAN - coded as dummy variable: $1=$ woman, $0=$ man

MARRIED - coded as dummy variable: $1=$ married/living with partner $0=$ all others. $\mathrm{DK} /$ Ref coded as missing. 
HOMEOWNER - coded as dummy variable: $1=$ homeowner $0=$ all others. DK/Ref coded as missing.

URBANLOCATION (all years) - generated based on Census data: population statistics for urban areas. Dummy variable: urban areas with population greater than 100,000 according to Census (top 29 largest cities) included as urban (coded 1), all others non-urban (coded 0), based on riding (if individual was in an 'urban' riding based on census population, coded 1 , all others coded 0 ).

ATLANTIC- coded as a dummy variable: $1=\mathrm{PEI} / \mathrm{NS} / \mathrm{NB} / \mathrm{Newfoundland} 0=$ others

ONTARIO - coded as a dummy variable: $1=$ Ontario $0=$ others

PRAIRIES - coded as a dummy variable: $1=$ Man/Sask $/ \mathrm{AB} 0=$ others

$\mathrm{BC}-$ coded as a dummy variable: $1=\mathrm{BC} 0=$ others

CATHOLIC - coded as a dummy variable: $1=$ Catholic $0=$ others. DK/Ref coded as missing.

ATHEIST - coded as a dummy variable: $1=$ non-religious $0=$ others. DK $/$ Ref coded as missing.

RETIRED - coded as a dummy variable: $1=$ retired $0=$ others. DK $/$ Ref coded as missing.

SELFEMPLOYED - coded as a dummy variable: $1=$ self-employed $0=$ others. DK $/$ Ref coded as missing.

FRENCHNATIVELANG - coded as a dummy variable: $1=$ French first language $0=$ others. DK/Ref coded as missing.

UNIONHOUSEHOLD - coded as dummy variable: $1=$ somebody in household belongs to union $0=$ others. DK/Ref coded as missing. Variable not included in 2004 analysis because of problem with the skip pattern in the question in survey: not all respondents were asked this question. 


\section{References}

Almond, Gabriel, and Sidney Verba. 1963. The Civic Culture: Political Attitudes and Democracy in Five Nations. Boston: Little, Brown and Company.

Archer, Keith, Roger Gibbins, Rainer Knopff, Heather MacIvor, and Leslie A. Pal. 2002. Parameters of Power: Canada's Political Institutions, $3^{\text {rd }}$ Edition. Scarborough, Thomson Nelson Learning

Bartels, Larry. 1996. Uninformed Votes: Information Effects in Presidential Elections. American Journal of Political Science 40 (1):194-230.

Bélanger, Paul, and Munroe Eagles. 2005. The Geography of Class and Religion in Canadian Elections Voting Revisited: A Research Note. Paper read at Canadian Political Science Association Annual Meeting, at University of Western Ontario, London, Ontario.

Berelson, Bernard R., Paul F. Lazarsfeld, and William N. McPhee. 1954. Voting: A Study of Opinion Formation in a Presidential Campaign. Chicago: University of Chicago Press.

Blais, André. 2005. Accounting for the Electoral Success of the Liberal Party in Canada. Presidential Address to the Canadian Political Science Association. Paper read at Canadian Political Science Association Annual Meeting, at University of Western Ontario, London, Ontario.

Blais, André, Elisabeth Gidengil, Richard Nadeau, and Neil Nevitte. 2002. Anatomy of a Liberal Victory: Making Sense of the Vote in the 2000 Canadian Election. Peterborough: Broadview Press, Ltd.

Brady, Henry, and Paul Sniderman. 1985. Attitude Attribution: A Group Basis for Political Reasoning. American Political Science Review 79:1061-1078.

Cairns, Alan. 1968. The Electoral System and the Party System in Canada, 1921-1965. Canadian Journal of Political Science 1 (1):55-80.

Cairns, Alan. 1977. The Governments and Societies of Canadian Federalism. Canadian Journal of Political Science 10.

Campbell, Angus, Philip E. Converse, Warren E. Miller, and Donald E. Stokes. 1960. The American Voter. Chicago: John Wiley \& Sons, Inc.

Canada, Statistics. 2001 Census. Population and Dwelling Counts and Population Rank, for Urban Areas.

Converse, Philip E. 1964. The Nature of Belief Systems in Mass Publics. In Ideology and 
Discontent, edited by D. E. Apter. New York: Free Press.

Cutler, Fred, and Richard W. Jenkins. 2000. Where One Lives and What One Thinks: Implications of Rural-Urban Opinion Cleavages for Canadian Federalism. Paper read at The Transformation of Canadian Political Culture and the State of the Federation, at Institute of Intergovernmental Affairs, Queen's University, Kingston, Ontario.

Dyck, Rand. 2000. Canadian Politics: Critical Approaches, $3^{\text {rd }}$ Edition. Scarborough, Nelson Thomson Learning.

Elections Canada. Canada's Federal Electoral Districts. http://www.elections.ca/content.asp?section=gen\&document $=\mathrm{ec} 92605 \&$ dir $=\mathrm{bkg} \&$ lang $=\mathrm{e} \&$ textonly $=$ false

Elections Canada. Historical 301 Electoral Districts Database. http://www.elections.ca/scripts/edwa301 historical/Default.asp?L=E\&Page=Sear chStart

Elections Canada. Transposition of population from 1996 Representation Order to 2003 Representation Order. http://www.elections.ca/cir/tran/transpop.pdf

Everitt, Joanna. 2002. Gender Gaps on Social Welfare Issues: Why Do Women Care? In Citizen Politics: Research and Theory in Canadian Political Behaviour, edited by B. O'Neill and J. Everitt. Toronto: Oxford University Press.

Gidengil, Elisabeth, André Blais, Richard Nadeau, and Neil Nevitte. 2003. Women to the Left? Gender Differences in Political Beliefs and Policy Preferences. In Women and Electoral Politics in Canada, edited by M. Tremblay and T. Linda. Oxford: Oxford University Press.

Horowitz, G. 1966. Conservatism, Liberalism, and Socialism in Canada: An Interpretation. The Canadian Journal of Economics and Political Science 32 (2):143-171.

Inglehart, Ronald, and Pippa Norris. 2000. The Developmental Theory of the Gender Gap: Women's and Men's Voting Behavior in Global Perspective. International Political Science Review 21 (4):441-63.

Irvine, William P. 1974. Explaining the Religious Basis of the Canadian Partisan Identity: Success on the Third Try. Canadian Journal of Political Science 7:560563.

Irvine, William P., and H. Gold. 1980. Do Frozen Cleavages Ever Go Stale? The Bases of the Canadian and Australian Party Systems. British Journal of Political Science $10(2): 187-218$. 
Iversen, Torben, and Frances Rosenbluth. 2006. The Political Economy of Gender: Explaining Cross-National Variation in the Gender Division of Labor and the Gender Voting Gap. American Journal of Political Science 50 (1):1-19.

Johnston, Richard. 1985. The Reproduction of the Religious Cleavage in Canadian Elections. Canadian Journal of Political Science 18 (1):99-113.

Johnston, Richard, André Blais, Henry E. Brady, and Jean Crete. 1992. Letting the People Decide: Dynamics of a Canadian Election. Stanford: Stanford University Press.

Lipset, Seymour Martin, and Stein Rokkan. 1967. Cleavage Structures, Party Systems and Voter Alignments: an Introduction". In Party Systems and Voter Alignments: Cross-National Perspectives, edited by S. M. Lipset and S. Rokkan. New York: The Free Press.

Lazarsfeld, Paul F., Bernard Berelson, and Hazel Gaudet. 1944. The People's Choice: How the Voter Makes Up His Mind in a Presidential Campaign. New York: Columbia University Press.

Lupia, Arthur, and Matthew McCubbins. 1998. The Democratic Dilemma. Cambridge: Cambridge University Press.

Luskin, Robert. 1990. "Explaining Political Sophistication” Political Behavior 12: 33162.

MacIvor, Heather. 1996. Women and Politics in Canada. Toronto: Broadview Press.

Matthews, J. Scott. 2006. The Campaign Dynamics of Economic Voting. Unpublished doctoral thesis: University of British Columbia, Vancouver, BC.

Meisel, John. 1956. Religious Affiliation and Electoral Behaviour: A Case Study. Canadian Journal of Economics and Political Science 22 (4):481-496.

Mendelsohn, Matthew, and Richard Nadeau. 1997. The Religious Cleavage and the Media in Canada. Canadian Journal of Political Science 30 (1):129-146.

Siegfried, André. 1907. The Race Question in Canada. London: E. Nash.

Sniderman, Paul, Richard Brody, and Philip Tetlock. 1991. Reasoning and Choice: Explorations in Political Psychology. New York: Cambridge University Press.

Statistics Canada. Census of Canada. Population and Dwelling Counts, for Census Metropolitan Areas and Census Agglomerations, 2001 and 1996 Censuses 100\% Data 
http://www12.statcan.ca/english/census01/products/standard/popdwell/TableCMA-N.cfm? $\mathrm{T}=1 \& \mathrm{SR}=1 \& \mathrm{~S}=3 \& \mathrm{O}=\mathrm{D}$

Tomz, Michael, Jason Wittenberg, and Gary King. 2003. Clarify: Software for Interpreting and Presenting Statistical Results. Journal of Statistical Software 8 (1). 